\title{
TOLERANSI BERAGAMA MASYARAKAT BALI, PAPUA, MALUKU
}

\author{
Ainna Amalia ${ }^{1}$, Ricardo Freedom Nanuru ${ }^{2}$ \\ STAI Miftahul Ula Kertosono Nganjuk ${ }^{1}$, Universitas Halmahera, Tobelo ${ }^{2}$ \\ Email: ainna_amalia@yahoo.co.id
}

\begin{abstract}
The focus of this research is the tolerance of the people of Bali, Maluku, and Papua. This quantitative research uses a survey method by taking 282 respondents who are at least 20 years old. As a result, $61.3 \%$ of respondents were the same with people of different religions and religions. $85.3 \%$ remained friends despite their religious differences. $60.6 \%$ of respondents still feel happy and comfortable with people who have different beliefs. And $66.3 \%$ of respondents often gave appreciation to friends and neighbors of different religions. Respondents also strongly disagree if there are actions that prevent adherents of other religions from carrying out their worship, which is as much as $78.5 \%$. They tend to give freedom of worship to different followers, as many as $84.9 \%$. In addition, as many as $56.3 \%$ of respondents released adherents of other religions to establish places of worship as long as they were in accordance with procedures. And $61.3 \%$ of respondents continued to establish cooperation in various fields with people of different religions. Conclusions from research conducted, the people of Bali, Maluku, and Papua, which are Muslim minority areas, still have a high tolerance towards other religions. So religious differences do not affect their tolerance
\end{abstract}

\section{Keywords: Religious Tolerance, Society}

\begin{abstract}
Abstrak
Fokus dari riset ini adalah toleransi masyarakat Bali, Maluku dan Papua. Riset kuantitatif ini menggunakan metode survey dengan mengambil 282 responden yang berusia minimal 20 tahun. Hasilnya sebanyak 61,3\% responden bersikap sama terhadap orang yang seagama dan beda agama. 85,3 \% tetap berteman meskipun beda agama. 60,6 \% responden tetap merasa senang dan nyaman terhadap orang yang berbeda keyakinan. Dan 66,3\% responden seringkali memberi apresiasi terhadap teman dan tetangga yang berbeda agama. Responden juga sangat tidak setuju jika ada tindakan yang menghalangi pemeluk agama lain melaksanakan ibadahnya, yaitu sebanyak 78,5\%. Mereka cenderung memberikan kebebasan beribadah kepada pemeluk yang berbeda, yaitu sebanyak 84,9\%. Selain itu sebanyak 56,3 \% responden membebaskan pemeluk agama lain mendirikan tempat ibadah asal sesuai dengan prosedur. Dan 61,3\% responden tetap menjalin kerjasama diberbagai bidang dengan orang yang berbeda agama. Kesimpulan dari riset yang dilalukan, masyarakat Bali, Maluku dan Papua, yang merupakan daerah muslim minoritas tetap memiliki toleransi yang cenderung tinggi terhadap pemeluk agama lain. Jadi perbedaan agama tidak mempengaruhi sikap toleransi mereka.
\end{abstract}

Kata Kunci : Toleransi Beragama, Masyarakat 


\section{A. Pendahuluan}

Bangsa Indonesia merupakan bangsa yang masyarakatnya majemuk. Terdiri dari ribuan kultur, etnis, bahasa dan agama. Bahkan ada yang menganggap bahwa Indonesia merupakan negara multikultural terbesar di dunia (Ginting Kiki. 2009; Gina Lestari. 2015; Amalia. 2016) Keragaman ini bisa menjadi berkah bagi bangsa, atau bisa sebaliknya. Tergantung bagaimana masyarakat Indonesia memaknai dan mensikapinya. Fakta di lapangan menunjukkan bahwa keragaman ini berpotensi menimbulkan konflik antar etnis, agama, dan budaya. Seperti konflik horisontal yang terjadi di Sambas, Poso, Sampit, Tasikmalaya dan lainlain. Korbannya tidak hanya nyawa yang melayang, tapi juga harta benda yang tak terhitung jumlahnya (Sudrajat. 2014; Rosyada. 2014; Yakin. 2005; Ibrahim. 2008)

Wajah multikultural di negeri ini, ibarat api dalam sekam, dapat meledak kembali kapan saja. Pemicunya bisa masalah-masalah politik, agama serta sosial budaya yang lagi memanas (Choirul Mahfud. 2010; Ibrahim. 2008; Suparlan. 2002). Kasus pengeboman di Surabaya 13-14 Mei 2018 lalu, merupakan bukti bahwa multikulturalisme di Indonesia berpotensi memunculkan konflik dan kekerasan dalam masyarakat. Untuk kasus bom Surabaya, agama menjadi pemicu terjadinya bom bunuh diri yang menewaskan belasan orang termasuk pelaku dan melukai puluhan masyarakat sipil. Hal ini menunjukkan bahwa masih ada problem dalam hal toleransi sebagian masyarakat Indonesia dalam mensikapi perbedaan,

Di era reformasi, kemajemukan masyarakat cenderung menjadi beban bagi bangsa Indonesia. Problem-problem disintegrasi bangsa bermula dari sikap intoleransi masyarakat yang berbeda latar belakang. Termasuk berbeda latar belakang agama. Padahal dalam perspektif keagamaan, nilai dasar setiap agama adalah toleransi. Dan seharusnya agama bisa menjadi energi positif untuk membangun nilai toleransi guna mewujudkan negara yang adil, sejahtera dan demokratis (Ainna Amalia FN, Muhammad Fahmi, Abdul Muhid. 2018). Pada era reformasi, seharusnya kita menjunjung tinggi nilai demokrasi dan toleransi. Demokrasi tanpa toleransi akan melahirkan tatanan politik yang otoritarianistik, sedangkan toleransi tanpa demokrasi akan melahirkan pseudo-toleransi, yaitu toleransi yang rentan konflik-konflik komunal (Lestari. 2015). 
Oleh sebab itu, demokrasi dan toleransi harus saling terkait, baik dalam komunitas masyarakat politik maupun masyarakat sipil. Disamping itu nilai dasar setiap agama adalah toleransi, terutama agama Islam tidak kurang dari 300 ayat menyebut mutiara toleransi secara eksplisit. Sehubungan dengan kedua hal tersebut, dipandang penting adanya toleransi dalam kehidupan masyarakat plural yang demokratis. Permasalahannya sekarang bahwa toleransi dalam kehidupan bersama semakin lemah, dan anti toleransi serta anti pluralisme semakin menguat. Untuk itu toleransi perlu dikembangkan dalam masyarakat plural (Ginting Kiki. 2009; Hanafy. 2015).

Di Indonesia, toleransi antar umat beragama merupakan hal yang sangat fundamental. Karena bangsa Indonesia merupakan negara dengan multi suku, agama dan ras. Merawat dan melanggengkan toleransi menjadi hal yang utama untuk menjaga keberlangsungan hidup bermasyarakat, berbangsa dan bernegara (Iksan. 2015). Secara umum toleransi sendiri mengacu pada sikap terbuka, lapang dada, suka rela dan kelembutan.

Wilayah-wilayah Indonesia yang memiliki beragam kultur, ras dan agama, memiliki potensi konflik yang sangat tinggi. Terlebih konflik yang berlatar belakang perbedaan agama. Oleh karenanya, riset yang berkaitan dengan toleransi beragama menjadi sangat penting. Selama ini kebanyakan riset toleransi beragama berfokus pada masyarakat yang memiliki tingkat keragaman beragama yang sangat tinggi. Ada yang beragama Islam, Kristen, Budha dan Hindu. Namun masih jarang riset toleransi pada masyarakat yang muslimnya minoritas, seperti di Bali, Papua dan Maluku. Oleh karenanya, penelitian ini berfokus pada hal tersebut.

\section{B. Landasan Teori}

Studi tentang toleransi telah banyak dilakukan. Salah satunya adalah penelitian tentang toleransi di Kota Bandung yang dilakukan oleh Rina Hermawati dkk (Rina Hermawati, Caroline Paskarina. 2016). Berdasarkan penelitian tersebut, indeks toleransi antar umat beragama di kota Bandung sebesar 3,82 termasuk dalam kategori "tinggi". hal ini yang mengindikasikan bahwa interaksi sosial antar umat beragama di Kota Bandung telah berlangsung secara 
baik dan berada dalam batas-batas jarak sosial yang wajar. Mayoritas responden memiliki persepsi positif terhadap toleransi antar umat beragama. Sebagaimana tercermin dalam sikap antarumat beragama yang bersedia menerima secara terbuka keberadaan pemeluk agama yang berbeda dalam ranah pergaulan sosial maupun profesi, meskipun sebatas pada dimensi publik atau formal dari pergaulan sosial. Di satu sisi, muncul juga kemungkinan konflik yang umumnya dipicu oleh perizinan pembangunan rumah ibadat yang berada dalam ranah kewenangan pemerintah. Isu agama masih menjadi faktor kuat untuk memicu sentimen berbasis identitas ingroup dan out-group, sehingga rentan memicu konflik (Rina Hermawati, Caroline Paskarina. 2016).

Selain penelitian Rina dkk, ada sebuah penelitian tentang toleransi yang dilakukan oleh Casram, tahun 2016. Bahwa toleransi agama merupakan keniscayaan untuk menjamin stabilitas sosial sebuah masyarakat. Kehidupan sosial dan agama hendaknya tidak tersisih dari satu sama lain, dan musti terintegrasi satu sama lain. Membangun masyarakat terdidik dan umat beragama yang berpikiran terbuka merupakan prasyarat untuk mencapai tujuan ini. Toleransi agama yang ideal mustinya dibangun melalui partisipasi aktif semua anggota masyakarat beragama yang beragam guna mencapai tujuan-tujuan yang sama atas dasar kebersamaan, sikap inklusif, rasa hormat dan saling-paham terkait pelaksanaan ritual dan doktrin-dokrtin tertentu dari masing-masing agama (Casram. 2016).

Selain itu, ada lagi penelitian tentang toleransi yang dilakukan oleh Baidi Bukhori. Penelitian ini menguji secara empiris pengaruh variabel fundamentalisme agama dan kontrol diri secara simultan terhadap toleransi pada umat Kristiani di Kota Semarang. Dan hasilnya adalah terdapat pengaruh fundamentalisme agama dan kontrol diri secara simultan terhadap toleransi pada umat Kristiani. Semakin tinggi fundamentalisme agama dan semakin rendah kontrol diri, maka semakin rendah toleransi terhadap umat Kristiani, sebaliknya semakin rendah fundamentalisme dan semakin tinggi kontrol diri maka semakin tinggi toleransi terhadap umat Kristiani.

Penelitian yang dilakukan oleh Bogardus juga mengkaji masalah toleransi. Kajiannya fokus pada pengukuran penerimaan seseorang terhadap orang lain yang 
memiliki karakteristik sosial budaya yang berbeda. Konsep Borgadus ini kemudian terkenal dengan istilah Social Distance Scale. Bahwa jarak sosial pada dasarnya diukur dari seberapa besar simpati yang dirasakan individu atau kelompok terhadap individu atau kelompok lain yang berbeda dengan dirinya. Skala ini kemudian banyak digunakan sebagai alat ukur toleransi sosial.

Secara rinci, pengukuran tersebut dioperasionalisasikan ke dalam skala yang mencakup rentang skor dari 1,00 hingga 7,00, di mana skor 1,00 berarti tidak ada jarak sosial. Skala yang dipakai Bogardus sebagai berikut: As close relatives by marriage (as the legal spouse of a close relative) (score 1.00) As my close personal friends (score 2.00) As neighbors on the same street (score 3.00) As co-workers in the same occupation (score 4.00) As citizens in my country (score 5.00) As non-citizen visitors in my country (score 6.00). Would exclude from entry into my country (score 7.00) (Bogardus. 1925 dalam Rina Hermawati, Caroline Paskarina. 2016).

Sedangkan definisi toleransi beragama (religious tolerance) sendiri tidak mudah ditemukan secara eksplisit. Sebagian besar studi tentang toleransi beragama lebih banyak mendeskripsikan sikap yang disebut toleran. Unesco mengartikan toleransi sebagai sikap saling menghormati, saling menerima, saling menghargai di tengah keragaman budaya, kebebasan berekspresi dan cerminan dari karakter manusia (Casram. 2016b).

Sikap toleransi harus didasari oleh cakrawala pengetahuan yang luas, keterbukaan, dialog, kebebasan berpikir. Pendek kata toleransi setara dengan sikap positif, dan menghargai orang lain dalam rangka menggunakan kebebasan asasi sebagai manusia. Toleransi juga merupakan suatu sikap atau perilaku manusia yang mengikuti aturan, di mana seseorang dapat menghargai, menghormati perilaku orang lain. Istilah Toleransi dalam konteks sosial budaya dan agama berarti sikap dan perbuatan yang melarang adanya diskriminasi terhadap kelompok atau golongan yang berbeda dalam suatu masyarakat (Bakar. 2015).

Toleransi beragama sendiri memiliki makna sikap menghargai dan menghormati masalah-masalah keyakinan yang berhubungan dengan akidah atau ketuhanan yang diyakini orang lain. Toleransi beragama juga merupakan sikap 
dan perbuatan yang melarang adanya diskriminasi terhadap kelompok atau golongan yang berbeda agama dan keyakinan dalam suatu masyarakat. Seseorang harus diberikan kebebasan untuk meyakini dan memeluk agama sesuai dengan pilihannya masing-masing. Serta memberikan kebebasan menjalankan ajaranajaran yang dianut atau diyakini tersebut (Bakar. 2015; Khotimah. 2013; Pamungkas. 2014). Toleransi beragama merupakan implementasi dari pengalaman keagamaan dalam bentuk komunitas. Ekspresi keberagamaan dalam komunitas ini merupakan tanggapan manusia beragama terhadap realitas mutlak dalam bentuk jalinan sosial antar umat seagama ataupun berbeda agama. Respon ini membuktikan bagi mereka bahwa realitas keberagaman merupakan keniscayaan manusia dalam pergaulan sosial. Wujud dari ekspresi keberagamaan ini menunjukkan tingkat kematangan seseorang dalam beragama (Ismail. 2012).

Dalam konteks hubungan antarumat beragama, intoleransi muncul ketika ada prasangka terhadap orang atau kelompok lain yang berada di luar dirinya. Gordon Allport menyebutkan tentang paradoks agama dan intoleransi (Allport. 1950). Menurutnya, agama turut bertanggung jawab atas munculnya prasangka. Kendati ada aspek universal dari setiap agama, tapi ketika ikatan-ikatan keagamaan itu terbentuk, maka perasaan in group akan muncul dan menyebabkan setiap orang yang berada di luar ikatan tersebut dianggap sebagai out group dan diperlakukan berbeda, bahkan tidak jarang dicurigai akan menganggu ketahanan ikatan tersebut. Dalam konteks inilah, konflik dan perilaku kekerasan yang mengatasnamakan agama menjadi rentan muncul (Allport. 1950; DeCarvalho. 1993; Sherif. 1954).

\section{Metode Penelitian}

Metode penelitian yang dipakai dalam penelitian ini adalah metode survey dengan menggunakan pendekatan kuantitatif. Pengumpulan data mengenai toleransi beragama dilakukan dengan menggunakan kuesioner. Dengan cara ini diharapkan bisa tergambar generalisasi pola toleransi. Sedangkan indikator dari toleransi sendiri adalah non diskriminatif, penerimaan, penghargaan, kebebasan dan kerjasama. Toleransi dalam hubungan antar umat beragama ini akan diukur melalui seberapa jauh para pemeluk agama menentukan jarak sosial mereka 
terhadap para pemeluk agama lainnya. Adapunjumlahresponden yang terlibat dalam riset ini sebanyak 282 responden yang berusia minimal 20 tahun. Responden perempuan sebanyak 46,8 \%, dan 53,2 \% responden laki-laki. 65,1\% responden beragama Islam, sisanya $34.9 \%$ beragama non muslim.

\section{Hasil Penelitian dan Pembahasan}

Bali, Papua dan Maluku merupakan Propinsi dengan jumlah masyarakat non muslim lebih banyak dibanding masyarakat muslim. Masing-masing dari 3 propinsi yang menjadi lokasi penelitian ini memiliki karakterisitk dan ciri khas yang berbeda-beda. Dari data sensus penduduk 2010, jumlah penduduk berdasarkan agama yang dianut di masing-masing lokasi penelitian adalah sebagai berikut:

Tabel 1 Jumlah Penduduk masing-masing Agama

\begin{tabular}{|l|l|l|l|l|l|}
\hline \multicolumn{1}{|c|}{ Propinsi } & \multicolumn{1}{c|}{ Islam } & \multicolumn{1}{c|}{ Kristen } & \multicolumn{1}{c|}{ Katolik } & \multicolumn{1}{c|}{ Hindu } & \multicolumn{1}{c|}{ Budha } \\
\hline Bali & 520244 & 64454 & 31397 & 3247283 & 21156 \\
\hline Papua & 450096 & 1855245 & 500545 & 2420 & 1452 \\
\hline Maluku & 776130 & 634841 & 103629 & 5669 & 259 \\
\hline
\end{tabular}

Sumber: Data Sensus Penduduk. 2010

Lokasi pertama Bali; masyarakat Bali mayoritas menganut agama Hindu (Kusuma. 2007); (Picard. 2008). Masyarakat selain beragama Hindu menjadi kelompok minoritas di pulau dewata ini (Samiyono. 2013). Masyarakat Bali merupakan masyarakat multi agama. Semua agama ada di Bali. Menurut Samiyono (2013) interaksi antar etnis, agama dan budaya bukanlah barang langka di Bali. Sejak jaman dahulu masyarakat Bali sudah terbiasa berinteraksi dengan multi etnnis dan agama. Sebab budaya Bali menjujung tinggi nilai-nilai keseimbangan dan harmonisasi antar manusia dengan Tuhan (perhyangan), dengan sesama (pawongan) dan dengan lingkungan (palemahan). Konsep ini disebut Tri Hita Karana. Namun, semenjak budaya Bali berorientasi pada jasa, dengan maraknya industri pariwisata, sikap masyarakat Bali mulai tidak lagi ramah dan harmoni. Ditambah peristiwa ledakan bom dalam bulan Oktober 2002 dan 2005, masyarakat Bali semakin berhati-hati terhadap para pendatang Terlebih yang berbeda atnis, budaya dan agama.

Lokasi kedua, Papua; Masyarakat Papua merupakan masyarakat multi etnis yang mayoritas beragama kristen. Papua identik dengan daerah penuh 
konflik dan kekerasan. Serta daerah penuh gejolak dan pemberontakan (Wekke, 2016). Konflik antar etnis yang sangat menyita perhatian publik adalah kekerasan antar umat beragama yang terjadi di Kabupaten Tolikara, Papua pada 2015. Peristiwa ini bertepatan saat perayaan Hari Raya Idul Fitri umat muslim. Konflik bernuansa SARA ini menjadikan wajah keragaman di tanah Papua sedikit memerah.

Lokasi ketiga, Maluku; Kondisi masyarakat maluku juga sangat rentan terhadap konflik terlebih konflik yang berlatar belakang agama. Padahal pada masa kerajaan Ternate dan kerajaan Tidore abad ke 17-18 masehi, masyarakatnya memiliki hubungan yang sangat harmonis. Kerajaan Ternate merepresentasikan masyarakat muslim sedang kerajaan Tidore merepresentasikan masyarakat non muslim. Akan tetapi ketika kaum imperialis datang pada abad 18, bibit-bibit konflik mulai tumbuh. Bangsa Portugis dan Spanyol berusaha memecah hubungan Ternate dan Tidore menjadi hubungan rivalitas. Puncaknya ketika bangsa Belanda mulai masuk ke Maluku pada abad ke-19 dengan tujuan menguasai sumber rempah-rempah.

Bibit konflik keagamaan ini sangat mengakar hingga tereskalasi pada rentang tahun 1999-2002. Dimulai ketika Belanda melakukan misionarisasi Kristen Protestan kepada warga lokal. Praktik misionarisasi Kristen yang dilakukan oleh Utrechtsche Zendings Vereeniging (UNZ) tersebut sebenarnya merupakan bagian dari upaya Belanda untuk mengurangi pengaruh Ternate yang masih kuat di Maluku (Hadi. 2007). Faktor inilah yang kemudian menjadikan Maluku menjadi tersegregasi baik secara politik maupun sosio keagamaan dimana Maluku utara yang masih berada dalam pengaruh Kerajaan Islam Ternate sendiri dinamakan sebagai Jazirah Leihitu sedangkan Maluku selatan yang berada dalam pengaruh misionarisasi Kristen Belanda dinamakan Jazirah Leitimur (Hadi. 2007).

Selain itu, semasa pemerintahan kolonial, warga Maluku Kristen banyak yang diangkat menjadi birokrat (ambtenaar) dan militer Belanda karena dianggap mau bekerja sama dengan pemerintah kolonial. Tidak hanya itu, masyarakat Kristen Maluku juga disekolahkan sedangkan kaum Islam Maluku cenderung diabaikan karena dianggap tidak mau bekerjasama dengan pemerintah Belanda. Akhirnya kaum Islam Maluku mengalami marjinalisasi dan diskrimasi sosial dan 
ekonomi semasa pemerintahan kolonial Belanda (John Pieris. 2004). Diskriminasi dan marjinalissi inilah dikemudian hari menguatkan rivalitas yang kemudian berkembang menjadi konflik agama.

Selanjutnya, dengan adanya fakta sejarah potensi konflik agama di Bali, Papua dan Maluku ini, maka berbagai cara ditempuh oleh pemerintah dan masyarakat untuk meminimalisir terjadi kembali konflik. Salah satu resolusi konflik yang digerakkan adalah membangun dan meningkatkan semangat toleransi masyarakat di Bali, Papua dan Maluku. Toleransi dibangun melalui pemahaman kearifan lokal di masing-masing wilayah. Di Bali kearifan lokal yang dihidupkan dan dikembangkan kembali adalah budaya menjujung tinggi nilai-nilai keseimbangan dan harmonisasi antar manusia dengan Tuhan (perhyangan), dengan sesama (pawongan) dan dengan lingkungan (palemahan). Konsep ini disebut Tri Hita Karana. Di Papua, masyarakatnya berusaha menghargai nilainilai agama dan nilai-nilai keraifan lokal seperti adanya usulan agar ucapan salam sejahtera disesuaikan dengan nilai adat istiadat. Selain itu, babarapa tokoh pemuda aktif melakukan dialog untuk mengkomunikasikan solidaritas dan pentingnya nilai-nilai toleransi untuk hidup bersama dengan damai dalam bingkai NKRI. Mereka juga menggerakkan keberadaan FKUB (Forum Kerukunan Umat Beragama) agar berjalan lebih dinamis untuk membangun sikap toleransi beragama masyarakat Papua.

Sedangkan kearifan lokal masyarakat Maluku adalah kitorang samua basudara (kita semua adalah bersaudara). Pemahaman tersebut merujuk pada konstruksi bahwa meskipun masyarakat Maluku sendiri terfragmentasi menjadi dua komunitas yakni salam (Islam) dan serani (Nasrani) tetap memiliki satu darah keturunan sama. Revitalisasi konsep tersebut juga dimaksudkan untuk mengikis liyan (the others) yang selama ini menjadi hambatan resolusi pedamaian. Secara filosofis kitorang basudara sendiri berfungsi secara dua arah yakni menjembatani adanya segregasi baik antara komunitas Salam (Islam) maupun komunitas Sarani (Kristen) dan membangun konsensus perdamaian berdasarkan nilai nilai sosio keagamaan yang berkembang dalam ranah setempat (John Pieris, 2004).

Kemudian, dari tiga lokasi penelitian yang sama-sama punya potensi konflik agama yang tinggi, ternyata memiliki pola toleransi yang hampir sama. 
Dari hasil angket yang disebarkan kepada 282 responden di 3 lokasi, menghasilkan data kuantitatif sebagai berikut: sebanyak $61,3 \%$ responden bersikap sama terhadap orang yang seagama dan beda agama. 85,3 \% tetap berteman meskipun beda agama. 60,6 \% responden tetap merasa senang dan nyaman terhadap orang yang berbeda keyakinan. Dan 66,3\% responden seringkali memberi apresiasi terhadap teman dan tetangga yang berbeda agama. Responden juga sangat tidak setuju jika ada tindakan yang menghalangi pemeluk agama lain melaksanakan ibadahnya, yaitu sebanyak 78,5\%. Mereka cenderung memberikan kebebasan beribadah kepada pemeluk yang berbeda, yaitu sebanyak $84,9 \%$. Selain itu sebanyak 56,3\% responden membebaskan pemeluk agama lain mendirikan tempat ibadah asal sesuai dengan prosedur. Dan 61,3\% responden tetap menjalin kerjasama diberbagai bidang dengan orang yang berbeda agama.

Dari data ini menunjukkan bahwa toleransi beragama masyarakat Bali, Papua dan Maluku yang sama-sama memiliki potensi konflik beragama dapat tumbuh dengan baik. Salah satu faktor berkembangnya toleransi beragama di 3 lokasi tersebut adalah dengan marawat dan meruwat nilai-nilai kearifan lokal masyarakat Bali, Papua dan Maluku yang sudah mereka miliki sejak zaman nenek moyang.

\section{E. Kesimpulan}

Nilai-nilai toleransi mutlak diperlukan oleh masyarakat yang memiliki keragaman etnis dan budaya serta agama. Oleh karena itu, menumbuhkan dan mengembangkan sikap toleransi menjadi keniscayaan. Tingkat toleransi masyarakat Bali, Papua dan Maluku yang merupakan masyarakat dengan jumlah muslim minoritas tetap memiliki toleransi yang cenderung tinggi terhadap pemeluk agama lain. Jadi perbedaan agama tidak mempengaruhi sikap toleransi mereka.

\section{Daftar Pustaka}

Ainna Amalia FN, Muhammad Fahmi, Abdul Muhid, N. and M. 2018. Multicultural Education and Tolerant Attitude of Students of Islamic Senior High School (MA) in Bali Indonesia. Surabaya.

Allport, G. W. 1950. Prejudice: A Problem In Psychological And Social 
Causation. Journal of Social Issues, 6(4 S), 4-23. https://doi.org/10.1111/j.1540-4560.1950.tb02175.x

Amalia, A. F. 2016. Internalisasi pendidikan multikutural dalam keluarga radikal di Surabaya Jawa Timur.

Bakar, A. 2015. Konsep toleransi dan kebebasan beragama. TOLERANSI: Media Komunikasi Umat Bergama, 7(2), 123-131.

Casram. 2016a. Membangun Sikap Toleransi Beragama Dalam Masyarakat Plural. Wawasan: Jurnal Ilmiah Agama Dan Sosial Budaya, 1, 2, 187-198.

Casram, C. 2016b. Membangun Sikap Toleransi Beragama dalam Masyarakat Plural. Wawasan: Jurnal Ilmiah Agama Dan Sosial Budaya, 1(2), 187. https://doi.org/10.15575/jw.v1i2.588

Choirul Mahfud. 2010. Pendidikan Multikultural (4th ed.). Yogjakarta: Pustaka Pelajar.

DeCarvalho, R. J. 1993. Gordon W. Allport on the Nature of Prejudice. Psychological Reports, 72, 299-308. https://doi.org/10.2466/pr0.1993.72.1.299

Gina Lestari. 2015. Bhinneka Tunggal Ika: Khasanah Multikultural Indonesia di tengah Kehidupan Sara. Jurnal Pendidikan Pancasila Dan Kewarganegaraan, $28 . \quad$ Retrieved from Journal.um.ac.id/index.php/jppk/article/view/5437/2037

Ginting Kiki, R. A. 2009. Toleransi dalam Masyarakat Plural. MAJALAH ILMIAH LONTAR, (Vol 23, No 4 (2009): Majalah Ilmiah Lontar).

Hadi, S. 2007. Disintegrasi Pasca Orde Baru: Negara, Konflik Lokal, dan Dinamika Internasional. Jakarta: Yayasan Obor.

Hanafy, M. S. 2015. Pendidikan Multikultural dan Dinamika Ruang Kebangsaan. Jurnal Diskursus Islam, 3(1), 119-139.

Ibrahim, R. 2008. Pendidikan Multikultural: Upaya Meminimalisir Konflik dalam Era Pluralitas Agama. El Tarbawi, 1(1), 115-127.

Iksan. 2015. Demokrasi, Hukum Islam Dan Toleransi Antar Umat Beragama. Fundamental, 4(1), 1-19.

Ismail, R. 2012. Konsep Toleransi Dalam Psikologi Agama (Tinjauan Kematangan Beragama. Religi, VIII(1), 1-12. https://doi.org/DOI: http://dx.doi.org/10.14421/rejusta.2012.\%25x

John Pieris. 2004. Tragedi Maluku: Sebuah Krisis Peradaban. Jakarta: Yayasan Obor. Retrieved from http://www.bukabuku.com/browses/product/9789794615133/tragedimaluku-sebuah-krisis-peradaban.html

Khotimah. 2013. Toleransi Beragama. Jurnal Ushuluddin.

Kusuma, I. N. W. 2007. Geguritan Nabi Muhammad: Cermin Akulturasi Budaya Hindu-Islam di Bali. Sari (ATMA), 25, 119-127.

Lestari, G. (2015). Bhinnekha Tunggal Ika : Khasanah Multikultural. Jurnal Pendidikan Pancasila Dan Kewarganegaraan, I(Februari), 31-37.

Pamungkas, C. 2014. Toleransi Beragama Dalam Praktik Sosial Studi Kasus Hubungan Mayoritas dan Minoritas Agama di Kabupaten Buleleng. Epistemé (Vol. 9).

Picard, M. 2008. Balinese identity as tourist attraction: From "cultural tourism" (pariwisata budaya) to "Bali erect" (ajeg Bali). Tourist Studies, 8(2), 155173. https://doi.org/10.1177/1468797608099246 
Rina Hermawati, Caroline Paskarina, N. R. 2016. Toleransi Antar Umat Beragama di Kota Bandung. UMBARA: Indonesian Journal of Anthropology, Volume 1, 105-115.

Rosyada, D. 2014. Pendidikan Multikultural di Indonesia Sebuah Pandangan Konsepsional. Sosio Didaktika, 1(1), 1-12.

Samiyono, D. 2013. Resistensi Agama Dan Budaya Masyarakat. Walisongo: Jurnal Penelitian Sosial Keagamaan, 21(2), 251-270. https://doi.org/10.21580/WS.21.2.244

Sherif, M. 1954. The Nature of Prejudice by Gordon W. Allport. Annals of the American Academy of Political and Social Science, 295, 171-172.

Sudrajat, S. 2014. Revitalisasi Pendidikan Multikultural Dalam Pembelajaran. Jurnal Pembangunan Pendidikan: Fondasi Dan Aplikasi, 2(1), 82-90. https://doi.org/10.21831/JPPFA.V2I1.2620

Suparlan, P. 2002. Menuju Masyarakat Indonesia yang Multikultural 1. Antropologi Indonesia, (3), 16-19.

Wekke, I. S. 2016. Harmoni Sosial Dalam Keberagaman Dan Keberagamaan Masyarakat Minoritas Muslim Papua Barat. Kalam, Volume 10, 295 - 312. Retrieved from https://www.researchgate.net/publication/316970423_Harmoni_Sosial_Dala m_Keberagaman_Dan_Keberagamaan_Masyarakat_Minoritas_Muslim_Pap ua_Barat

Yakin, M. A. 2005. Pendidikan Multikultural; Cross Cultural Understanding untuk Demokrasi dan Keadilan. Yogyakarta: Pilar Media. 